\title{
Effect of partial replacement of marine protein and oil sources in presence of lyso-lecithin in the diet of tiger shrimp Penaeus monodon Fabricius, 1978
}

\author{
H. IMRAN KHAN ${ }^{2}$, E. P. MADHUBABU ${ }^{3}$, R. JANNATHULLA ${ }^{4}$, K. AMBASANKAR ${ }^{1}$ \\ AND J. SYAMA DAYAL ${ }^{1}$ \\ ${ }^{1}$ ICAR-Central Institute of Brackishwater Aquaculture, 75, Santhome High Road, RA Puram, Chennai - 600028 \\ Tamil Nadu, India \\ ${ }^{2}$ ACI Godrej Agrovet Pvt. Ltd., Ja-28/8/B, Mohakhali, C/A, Dhaka-1212, Bangladesh \\ ${ }^{3} S G S$ India Pvt. Ltd., 28 B/I and B/2 SP BNT Connections Building, $2^{\text {nd }}$ Main Road, Ambattur Industrial Estate \\ Chennai - 600 058, Tamil Nadu, India \\ ${ }^{4}$ Sonac Feeds (India), Podalukur-Rapur Main Road, Inukurthy Panchayat, Nellore - 524 345, Andhra Pradesh, India \\ e-mail: amanimran1986@gmail.com
}

\begin{abstract}
A 42-days growth trail was performed to evaluate the effect of lyso-lecithin in Penaeus monodon ( $5.08 \pm 0.08 \mathrm{~g}$ ) in terms of growth and carcass fatty acid composition. Three iso-nitrogenous and iso-lipidic diets were prepared by partially replacing both marine protein and oil sources using plant based ingredients in the presence of soy-lecithin or lyso-lecithin. Each experimental diet was randomly allotted to three tanks with fifteen shrimps per tank and all the tanks were equipped with the flow-through system. Results revealed that shrimp fed diet with lyso-lecithin had significantly $(\mathrm{p}<0.05)$ higher specific growth rate, SGR (2.15) and daily growth coefficient, DGC (1.44) than those fed soy-lecithin (1.91 and 1.25 respectively). The growth pattern, feed and protein efficiency measures were not only better with lyso-lecithin compared to soy-lecithin and also on par with the control group. However, there was no significant difference in survival (82.22 to $84.44 \%)$ between the dietary treatments. The fatty acid composition of diets to a certain extent was reflected in the carcass composition of shrimp. The most essential fatty acids viz., eicosapentaenoic and docosahexaenoic acids were significantly $(\mathrm{p}<0.05)$ higher in shrimp fed lyso-lecithin supplemented diet. Present results suggest that lyso-lecithin enhances growth performance of P. monodon and carcass fatty acid composition compared to soy-lecithin due to its high emulsification properties with partial replacement of marine sources.
\end{abstract}

Keywords: Fatty acid, Fishmeal, Fish oil, Lyso-lecithin, Penaeus monodon, Shrimp nutrition

\section{Introduction}

Aquafeed is accounting about $4 \%$ of the total industrial feed produced, but it is consuming approximately 70 to $80 \%$ of available fishmeal and fish oil resources, respectively (Altech Feed Survey, 2015). This skewed pattern of consumption of the finite marine resources throws a challenging task to the fish nutritionists to identify sustainable cost-effective alternatives. Research efforts were made to replace both fishmeal and fish oil in shrimp feed with various vegetable protein and oil sources (Catacutan, 1991; Gonzalez-Felix and Perez-Velazquez, 2002; Kumaraguruvasagam et al., 2005; Dayal et al., 2011; Rajaram et al., 2012). These research efforts have resulted in the reduction of fish in/fish out ratio (FIFO) to a certain extent in aquafeeds. FIFO ratio is the requirement $(\mathrm{kg})$ of wild caught fish in terms of fishmeal and fish oil to produce one $\mathrm{kg}$ of farmed shrimp/fish (IFFO, 2009). Though the production from aquaculture sector has been doubled in 2010 compared to 2000, the FIFO ratio declined irrespective of the species. It could be due to the reduced inclusion level of fishmeal in the diets. Increasing fishmeal and fish oil production with the present global scenario is not exhibited in a positive way and hence the researchers switched over to other ingredients (Tacon and Metian, 2008). It is anticipated that the reduction of these marine sources in aqua feeds reduces the nutrient balance in diet, which negatively influences the growth pattern of cultured species. Despite research efforts, the inclusion frequency of fish oil is $80 \%$ compared to palm oil (3.1\%), coconut oil (3.1\%) and peanut oil (3.1\%).

The strategy to include vegetable protein and oil sources should not compromise the production performance and final product quality. In our earlier study, a combination of plant protein sources partially replaced fishmeal (Rajaram, 2010; Panigrahi et al., 2010; Dayal et al., 2011). Of all the vegetable oils, palm oil is the cheapest one (639.8 USD per ton) compared to soybean oil (721.2 USD per ton), coconut oil (1471.7 USD per ton) and peanut oil (1489.2 USD per ton) 
and the production of palm oil was around 66.9 million $t$ in 2016 (USDA, 2017). However, the utilisation of vegetable oils, in particular palm oil in shrimp feeds is limited due to the higher content of saturated fatty acids (SFAs). Merican and Shim (1994) stated that SFAs are less digestible compared to the polyunsaturated fatty acids (PUFA) which are abundant in marine oil sources, especially in fish oil. Polin et al. (1980) and Danicke et al. (2001) suggested that this could be due to the limited incorporation of SFAs into micelles. The effect of dietary phospholipids on digestion of certain oil sources viz., olive oil (Glencross et al., 1998), vegetable oils (Kumaraguruvasagam et al., 2005) and soybean oil (Yi Hu et al., 2011) have been studied earlier in penaeid shrimp species. The results indicated that phospholipids have a positive effect on solubilisation, emulsification and digestion of lipids. Lyso-lecithin is a product of phospholipase $A_{2}$ enzymatic activity of lecithin and was more effective than bile and soy-lecithin since it can form very small micelle (Zubay, 1983; Longmuir, 2002). Kontara et al. (1998) studied the efficacy of native, lyso and hydrogenated soy-lecithin in post-larval stages of Penaeus japonicus with semi-purified diets. It is hypothesised that inclusion of lyso-lecithin is more useful in shrimp due to its very short gut passage time by enhancing the digestibility and transportation of fatty acids in plant-based diets. However, the effect of lyso-lecithin on the growth, carcass composition of fatty acid and lipid profiles in shrimp is scarce in the available literature. Hence, the present study aimed to investigate the influence of lyso-lecithin with partial replacement of marine protein and oil sources in tiger shrimp, Penaeus monodon Fabricius, 1978.

\section{Materials and methods}

\section{Experimental diets}

A control diet was formulated using locally available ingredients based on the nutritional requirement of P. monodon. Two more iso-nitrogenous and iso-lipidic test diets were prepared by replacing marine protein sources partially with the combination of plant protein sources based on their individual best performance, balancing of essential amino acid profiles and digestibility as per our previous studies (Panigrahi et al., 2010; Rajaram, 2010; Dayal et al., 2012). In addition, 50\% of fish oil was replaced in test diets using palm oil and the test diets, Diet-SL and Diet-LL were having soy-lecithin (Real Soy Enterprises, Madhya Pradesh, India) and lyso-lecithin (Godrej Agrovet Ltd, Andhra Pradesh, India), respectively as a source of phospholipids. Experimental diets were prepared as per the method of Dayal et al. (2003). Briefly, the coarse ingredients listed in the formula (Table 1) were powdered in a micopulveriser and passed through $250 \mu \mathrm{m}$ mesh screen. All the dry ingredients were mixed in a domestic mixer for $10 \mathrm{~min}$ for homogenisation. Fish oil/palm oil
Table 1. Ingredient composition of experimental diets

\begin{tabular}{|c|c|c|c|}
\hline \multirow{2}{*}{ Ingredients } & \multirow{2}{*}{ Control diet } & \multicolumn{2}{|c|}{ Test diets } \\
\hline & & Diet-SL $^{1}$ & Diet-LL ${ }^{2}$ \\
\hline Fishmeal $^{3}$ & 25.0 & 15.0 & 15.0 \\
\hline Acetes $^{4}$ & 12.0 & 8.0 & 8.0 \\
\hline Prawn head & 5.0 & 5.0 & 5.0 \\
\hline Squid & 5.0 & 2.5 & 2.5 \\
\hline Soybean cake & 22.0 & 24.0 & 24.0 \\
\hline Soya flour & 0.0 & 4.0 & 4.0 \\
\hline Wheat gluten meal & 0.0 & 4.0 & 4.0 \\
\hline Corn gluten meal & 0.0 & 6.0 & 6.0 \\
\hline Groundnut oil cake & 0.0 & 2.5 & 2.5 \\
\hline Sesame oil cake & 0.0 & 2.5 & 2.5 \\
\hline Wheat & 10.9 & 8.9 & 8.9 \\
\hline Maida & 8.0 & 6.0 & 6.0 \\
\hline Broken rice & 5.0 & 4.0 & 4.0 \\
\hline Fish oil ${ }^{3}$ & 2.0 & 1.0 & 1.0 \\
\hline Palm oil & 0.0 & 1.0 & 1.0 \\
\hline Soy-lecithin & 2.0 & 2.0 & 0.0 \\
\hline Lyso-lecithin & 0.0 & 0.0 & 2.0 \\
\hline Vit. $\min -\mathrm{mix}^{5}$ & 2.0 & 2.0 & 2.0 \\
\hline Mineral mix ${ }^{6}$ & 0.0 & 0.5 & 0.5 \\
\hline Stable vitamin C & 0.1 & 0.1 & 0.1 \\
\hline Binder & 1.0 & 0.8 & 0.8 \\
\hline Cholesterol & 0.0 & 0.2 & 0.2 \\
\hline
\end{tabular}

'Soy-lecithin; '2yso-lecithin; ${ }^{3}$ Bismi Fisheries, Mayiladuthurai, Tamil Nadu, India; ${ }^{4}$ Mantis shrimp used as a protein source

${ }^{5}$ Vitamin mix (mg kg${ }^{-1}$ feed): Vitamin A - 10000 IU, D - 1500 IU, E - $60 \mathrm{mg}$, K - $1.5 \mathrm{mg}$, Niacin - $200 \mathrm{mg}$, Riboflavin - $37.5 \mathrm{mg}$, Calcium pantothenate - 125 $\mathrm{mg}$, B12 - $20 \mathrm{mg}$, Thiamin - $15 \mathrm{mg}$, Pyridoxine - $15 \mathrm{mg}$, Folic acid - $5.5 \mathrm{mg}$, Bbiotin - $750 \mathrm{mg}$, Choline chloride - $100 \mathrm{mg}$ and C $-1000 \mathrm{mg}$

${ }^{5 \times 6}{ }^{\mathrm{Mine}} \mathrm{Mal}$ mix (mg kg-1 feed): Cobalt - $0.2 \mathrm{mg}$; Iodine - $0.6 \mathrm{mg}$; Copper - $5.0 \mathrm{mg}$, Iron - $14.0 \mathrm{mg}$, Manganese - $55.0 \mathrm{mg}$, Zinc - $24.0 \mathrm{mg}$ and Dicalcium phosphate (1\%)

and soy-lecithin/lyso-lecithin were gradually added to the homogenised mash. Water was then added at the rate of $500 \mathrm{ml} \mathrm{kg}^{-1}$ of mash and manually kneaded into dough. It was steamed for $5 \mathrm{~min}$ at atmospheric pressure and pelleted in a table top pelletiser with a $2 \mathrm{~mm}$ dia die. The pellets were dried in a forced-air oven at $60^{\circ} \mathrm{C}$ for $12 \mathrm{~h}$ and stored at $-4^{\circ} \mathrm{C}$ until used.

\section{Experimental condition}

Post-larvae (PL 15) of P. monodon were procured from the private hatchery located near Chennai, India and was reared in net cages at the Muttukadu Experimental Station, ICAR-Central Institute of Brackishwater Aquaculture (ICAR-CIBA), Chennai, India. A total of 135 healthy shrimps $(5.08 \pm 0.08 \mathrm{~g})$ were randomly distributed into nine oval $5001(1.31 \times 0.64 \times 0.73 \mathrm{~m})$ fiberglass tanks (three tanks per feed and fifteen shrimps per tank) in a completely randomised design after acclimatisation (7 days) to the experimental condition. During acclimatisation, shrimps were fed a control diet having 39\% crude protein and $7 \%$ ether extract. The experiment was conducted in a flow-through system $\left(1.5 \mathrm{ml} \mathrm{min}^{-1}\right)$ for 42 days. During 
the experimental period, shrimps were fed the respective diet thrice a day (at 08:30, 12:30 and 18:00 hrs). One hour after every feeding, the uneaten feed was bottom-siphoned and dried at $60^{\circ} \mathrm{C}$ in a hot air oven overnight to calculate the feed intake on a daily basis. At the end of the growth trial, specific growth rate (SGR), daily growth coefficient (DGC), feed conversion ratio (FCR), protein efficiency ratio (PER), apparent protein utilisation (APU) and survival for each dietary treatment were determined as per Rajaram et al. (2012). During the growth trial, the water temperature, salinity and dissolved oxygen were in the range of 26 to $28.5^{\circ} \mathrm{C}, 28$ to $29 \mathrm{~g} \mathrm{l}^{-1}$ and 6 to $8 \mathrm{mg} \mathrm{l}^{-1}$, respectively.

\section{Biochemical analysis}

Proximate compositions of experimental diets and whole shrimp were analysed by standard methods of AOAC (1995). The analysis of total lipid, cholesterol, triacylglycerides and phospholipids were done as per Folch et al. (1957), Parekh and Jung (1970), Rice (1970) and Fiske and Subbarow (1925), respectively. Fatty acid methyl esters (FAMEs) were prepared according to Metcalfe et al. (1966). Briefly, lipids were transesterified with BF3-methanol and $0.5 \mathrm{~N}$ methanolic sodium hydroxide and the FAMEs were extracted into petroleum ether. Routine analysis of methyl esters was performed by a gas chromatograph (GC-2014 Shimadzu) on a RTX wax capillary column $(30 \mathrm{~m}$ length $\mathrm{x} 0.25 \mathrm{~mm}$ internal diax $0.2 \mu \mathrm{m}$ film thickness). Nitrogen was used as the carrier gas at a linear velocity of $37.5 \mathrm{~cm} \mathrm{sec}^{-1}$. The oven temperature was increased from 100 to $140^{\circ} \mathrm{C}$ at $10^{\circ} \mathrm{C} \mathrm{min}^{-1}$ and held for $5 \mathrm{~min}$ followed by the increase of $2.5^{\circ} \mathrm{C} \mathrm{min}^{-1}$ to $240^{\circ} \mathrm{C}$ and held for $5 \mathrm{~min}$ and finally reached to $245^{\circ} \mathrm{C}$ by increasing $2^{\circ} \mathrm{C} \mathrm{min}{ }^{-1}$ for $5 \mathrm{~min}$. The operating temperature for injection ports and flame ionisation detector were 260 and $250^{\circ} \mathrm{C}$, respectively. Compounds were identified by comparing with retention times of 37 component FAME mix (Supelco-Sigma).

\section{Statistical analysis}

Completely randomised design (CRD) was adopted and the data were statistically analysed using SPSS17.0. After one way analysis of variance, the means were compared using the Duncan's multiple range test (DMRT) at a significance level of $\mathrm{p}<0.05$ and the results were presented as means \pm SD. Prior to statistical evaluation, data were checked for determining the homogeneity of variance after ascertaining the normal distribution.

\section{Results and discussion}

\section{Nutritional composition of experimental diets}

Proximate, lipid class and fatty acid composition of test diets are shown in Table 2. The diets contained 39\% of crude protein and $7 \%$ of ether extract. Of all the analysed
Table 2. Proximate, lipid class and fatty acid composition of experimental diets

\begin{tabular}{|c|c|c|c|}
\hline \multirow{2}{*}{ Particulars } & \multirow{2}{*}{ Control diet } & \multicolumn{2}{|c|}{ Test diets } \\
\hline & & Diet-SL & Diet-LL \\
\hline \multicolumn{4}{|c|}{ Proximate composition ( $\%$ fed basis) } \\
\hline Moisture & 9.38 & 9.21 & 8.97 \\
\hline Crude protein & 39.84 & 39.38 & 39.76 \\
\hline Ether extract & 7.17 & 7.18 & 7.15 \\
\hline Crude fiber & 3.52 & 4.89 & 4.91 \\
\hline Nitrogen free extract ${ }^{1}$ & 26.06 & 26.63 & 26.30 \\
\hline Total ash & 14.02 & 12.71 & 12.91 \\
\hline \multicolumn{4}{|c|}{ Lipid class composition (\% total lipid) } \\
\hline Phospholipids & 27.17 & 21.87 & 23.61 \\
\hline Triacylglycerides & 45.30 & 57.41 & 56.17 \\
\hline Cholesterol & 5.18 & 4.71 & 4.72 \\
\hline \multicolumn{4}{|c|}{ Fatty acid composition (\% total fatty acid) } \\
\hline C14:0 & 5.20 & 2.92 & 2.61 \\
\hline C15:0 & 0.32 & 0.17 & 0.18 \\
\hline C16:0 & 18.53 & 27.59 & 26.73 \\
\hline $\mathrm{C} 16: 1$ & 4.74 & 2.83 & 2.96 \\
\hline $\mathrm{C} 17: 0$ & 0.68 & 0.31 & 0.29 \\
\hline $\mathrm{C} 17: 1$ & 0.81 & 0.25 & 0.21 \\
\hline C18:0 & 4.53 & 4.03 & 4.37 \\
\hline C18:1n-9 & 12.91 & 21.01 & 21.96 \\
\hline C18:1 n-7 & 2.42 & 1.41 & 1.48 \\
\hline C18:2 n-6 & 17.73 & 22.75 & 23.02 \\
\hline $\mathrm{C} \gamma \mathrm{18}: 3 \mathrm{n}-6$ & 0.23 & 0.19 & 0.13 \\
\hline $\mathrm{Ca} 18: 3 n-3$ & 3.70 & 2.30 & 2.21 \\
\hline $\mathrm{C} 20: 0$ & 0.34 & 0.41 & 0.45 \\
\hline C20:1 & 0.37 & 0.27 & 0.26 \\
\hline$C 20: 4 n-6$ & 1.12 & 0.47 & 0.46 \\
\hline$C 20: 5 n-3$ & 7.91 & 2.84 & 2.92 \\
\hline $\mathrm{C} 22: 0$ & 0.74 & 0.52 & 0.47 \\
\hline $\mathrm{C} 24: 0$ & 0.38 & 0.31 & 0.30 \\
\hline C22:6n-3 & 8.61 & 3.75 & 3.58 \\
\hline $\mathrm{C} 24: 1$ & 0.31 & 0.47 & 0.38 \\
\hline$\Sigma$ SFA & 30.73 & 36.26 & 35.40 \\
\hline$\Sigma$ MUFA & 21.56 & 26.24 & 27.25 \\
\hline$\Sigma$ PUFA and HUFA & 39.47 & 32.31 & 32.32 \\
\hline$\Sigma \mathrm{n}-3$ & 20.21 & 8.89 & 8.71 \\
\hline$\Sigma \mathrm{n}-6$ & 19.26 & 23.42 & 23.61 \\
\hline$n-3 / n-6$ & 1.05 & 0.38 & 0.37 \\
\hline
\end{tabular}

${ }^{1}$ Calculated by a difference

lipid fractions, triacylglycerides was found pre-dominant in all the diets, however; its level was high in both the test diets (56.17 to $57.41 \%$ ) compared to control diet (45.30\%). The level of phospholipids was higher in control diet (27.17\%) while it was $21.87 \%$ in Diet-SL and $23.61 \%$ in Diet-LL. Cholesterol content was relatively constant in all the diets (4.71 to $5.18 \%$ ). The fatty acid profile of the ingredients used in the formulation to a certain extent was reflected in the respective diets (Table 2). Fatty acids 
like $16: 0,18: 1 n-9$ and $18: 2 n-6$ were found to be high in control diet compared to both the test diets, whereas the reverse trend was observed for 14:0, 16:1, 17:1, 20:5n-3 and 22:6n-3. The sum of SFAs and MUFAs was 30.73 and $21.56 \%$, respectively in control diet and was increased to a range of $35.40-36.26 \%$ and $26.24-27.25 \%$ due to the partial replacement of marine sources. The sum of PUFAs was $39.47 \%$ in control diet and decreased in test diets (32\%). Though the level of n-3 and n- 6 was almost similar to control diet, wide variation was observed between them in both the test diets. Hence n-3/n- 6 ratio was reduced to $0.37-0.38$ in test diets while the ratio was comparatively high in control diet (1.05).

\section{Growth performance}

The substitution of marine protein and oil sources by using plant protein and oil sources did not affect the survival of $P$. monodon and was in the range of 82.22 to $84.44 \%$ indicating the possibility of partial replacement of marine sources in shrimp feed. However, the dietary treatments significantly $(\mathrm{p}<0.05)$ affected the growth performance of P. monodon in the present study (Table 3). Shrimp fed control diet had SGR and DGC of 2.18 and 1.46 respectively and the performance was on par with shrimp fed Diet-LL (2.15 and 1.44) whereas significantly $(\mathrm{p}<0.05)$ lower growth performance was observed in the group fed with Diet-SL (Table 3). There was no

Table 3. Effect of partial replacement of marine protein and oil sources using plant origins in the presence of lysolecthin on growth performance of Penaeus monodon ( $\mathrm{n}=3$; mean $\pm \mathrm{SD}$ )

\begin{tabular}{llll}
\hline \multirow{2}{*}{ Particulars } & \multirow{2}{*}{ Control diet } & \multicolumn{2}{c}{ Test diets } \\
\cline { 3 - 4 } & & Diet-SL & Diet-LL \\
\hline Final weight (g) & $12.78^{\mathrm{b}} \pm 0.31$ & $11.30^{\mathrm{a}} \pm 0.33$ & $12.52^{\mathrm{b}} \pm 0.37$ \\
$\mathrm{SGR}^{1}$ & $2.18^{\mathrm{b}} \pm 0.06$ & $1.91^{\mathrm{a}} \pm 0.07$ & $2.15^{\mathrm{b}} \pm 0.07$ \\
$\mathrm{DGC}^{2}$ & $1.46^{\mathrm{b}} \pm 0.05$ & $1.25^{\mathrm{a}} \pm 0.04$ & $1.44^{\mathrm{b}} \pm 0.05$ \\
$\mathrm{FCR}^{3}$ & $1.92^{\mathrm{a}} \pm 0.05$ & $2.08^{\mathrm{b}} \pm 0.04$ & $1.95^{\mathrm{a}} \pm 0.03$ \\
PER $^{4}$ & $1.43^{\mathrm{b}} \pm 0.03$ & $1.31^{\mathrm{a}} \pm 0.02$ & $1.40^{\mathrm{b}} \pm 0.02$ \\
APU (\%) & $27.17^{\mathrm{c}} \pm 0.64$ & $23.65^{\mathrm{a}} \pm 0.40$ & $25.30^{\mathrm{b}} \pm 0.34$ \\
Survival (\%) & $82.22 \pm 10.18$ & $84.44 \pm 7.70$ & $84.44 \pm 3.85$ \\
\hline
\end{tabular}

Means bearing different superscript letters within the row significantly $(\mathrm{p}<0.05)$ differ

${ }^{1}$ Specific growth rate; ${ }^{2}$ Daily growth coefficient; ${ }^{3}$ Feed conversion ratio; ${ }^{4}$ Protein efficiency ratio; ${ }^{5}$ Apparent protein utilisation

significant difference in FCR and PER between control and lyso-lecithin fed shrimps whereas significant $(p<0.05)$ increase in FCR and decrease in PER were observed in a group fed diet with soy-lecithin. Among the dietary treatments, though APU was better in the control group $(27.17 \%)$ significantly $(\mathrm{p}<0.05)$ higher value was noticed in shrimp fed diet with lyso-lecithin $(25.30 \%)$ than those fed soy-lecithin $(23.65 \%)$.
The level of each plant protein sources used in the present study to substitute marine proteins was within the range of our previous studies showing their support of adequate shrimp growth between control and lyso-lecithin diet (Panigrahi et al., 2010; Rajaram, 2010; Dayal et al., 2012). Though the combined replacement of both marine protein and oil sources would have resulted in the reduced growth performance slightly, a significant $(p<0.05)$ increase was observed with lyso-lecithin than soy-lecithin based diet. Khan et al. (2018) suggested that this is attributed to the improvement in the overall lipid digestibility, in particular fatty acids in P. monodon as a result of increased solubilisation and emulsification of the lipid due to the presence of lyso-lecithin. Schwarzer and Adams (1996) reported that lyso-lecithin forms micelles that are very small and more stable than those formed with other phospholipids or emulsifier such as lecithin and bile salt. Zubay (1983) and Longmuir (2002) documented that critical micelle concentration (CMC) formed by lyso-lecithin was in the range of 0.02 to $0.20 \mathrm{~mm} \mathrm{l}^{-1}$, which is 20 to 200 times more effective than bile $\left(\mathrm{CMC}=4 \mathrm{~mm} \mathrm{l}^{-1}\right.$ and lecithin $\left(\mathrm{CMC}=0.3-2 \mathrm{~mm} \mathrm{l}^{-1}\right)$. Reynier et al. (1985) indicated that micelle size is one of the most important factors that determine the absorption of lipid and lipophilic substances. Melegy et al. (2010) and Bingkun et al. (2011) observed a better digestibility with lyso-lecithin in broiler rations due to the enhanced efficiency of micelle formation. This would be a reason for obtaining a better result with lyso-lecithin than soy-lecithin in our study by increasing the absorption of lipid and lipid soluble substances from shrimp gut.

Many studies have demonstrated that HUFAs, in particular eicosapentaenoic acid (EPA; 20:5) and decoxahexonoic acid (DHA; 22:6) are preferentially incorporated and conserved in the polar lipid of crustacean tissue (Clarke, 1970; Kanazawa et al., 1977; D'Abramo et al., 1980; D'Abramo and Sheen, 1993). Even though Diet-LL is lower in both phospholipid and HUFA content, shrimp fed with lyso-lecithin supplemented diet is having higher HUFA content. This is due to the higher CMC formed by lyso-lecithin compared to bile and lecithin. This CMC ability would have increased the ability of the shrimp for better absorption (Longmuir, 2002) and also selective retention of HUFA (Xu et al., 1994; Deering et al., 1997). But in contrast, the improved performance with lyso-lecithin was not in agreement with the findings of Kontara et al. (1998) in post-larval stages of P. japonicus fed with semi-purified diets. The better performance in lyso-lecithin supplemented diets is due to the higher emulsification capacity of the lyso-lecithin diet in shrimp (Melegy et al., 2010). Bingkun et al. (2011) observed a better digestibility with lyso-lecithin in broiler rations due to the enhanced efficiency of micelle formation. 
This would be a reason for obtaining better result with lyso-lecithin than soy-lecithin in our study by increasing the absorption of lipid and lipid soluble substances from shrimp gut (Khan et al., 2018). Whereas, Kontara et al. (1998) supplemented phosphatidylcholine as a dietary source. Kumaraguruvasagam et al. (2005) reported that juveniles of penaeid shrimps are less sensitive to dietary phospholipids. However; the practical feed ingredients would have supplied phospholipids with the presence of unsaturated fatty acids in sn-2 position of the phospholipid molecules (D'Abramoand and Sheen, 1993; Coutteau et al., 1997; Gonzalez-Felix et al., 2002).

\section{Carcass composition of P. monodon}

Carcass proximate composition of $P$. monodon fed different diets is presented in Table 4. No significant differences were observed in the body composition of $P$. monodon among the dietary treatments except ether extract. Its level was found significantly $(p<0.05)$ high in

Table 4. Carcass proximate composition (\% wet weight basis) of Penaeus monodon fed experimental diets $(\mathrm{n}=3$; mean $\pm \mathrm{SD})$

\begin{tabular}{llll}
\hline \multirow{2}{*}{ Particulars } & \multirow{2}{*}{ Control diet } & \multicolumn{2}{c}{ Test diets } \\
\cline { 3 - 4 } & & Diet-SL & Diet-LL \\
\hline Moisture & $75.09^{\mathrm{a}} \pm 0.58$ & $75.62^{\mathrm{a}} \pm 0.43$ & $75.20^{\mathrm{a}} \pm 0.60$ \\
Crude protein & $18.73^{\mathrm{a}} \pm 0.34$ & $18.09^{\mathrm{a}} \pm 0.33$ & $18.46^{\mathrm{a}} \pm 0.32$ \\
Ether extract & $0.87^{\mathrm{a}} \pm 0.08$ & $1.11^{\mathrm{b}} \pm 0.07$ & $1.18^{\mathrm{b}} \pm 0.09$ \\
Crude fiber & $0.65^{\mathrm{a}} \pm 0.02$ & $0.65^{\mathrm{a}} \pm 0.06$ & $0.72^{\mathrm{a}} \pm 0.06$ \\
Nitrogen free extract & $0.99^{\mathrm{a}} \pm 0.29$ & $1.07^{\mathrm{a}} \pm 0.09$ & $0.94^{\mathrm{a}} \pm 0.27$ \\
Total ash & $3.64^{\mathrm{a}} \pm 0.10$ & $3.51^{\mathrm{a}} \pm 0.07$ & $3.59^{\mathrm{a}} \pm 0.25$ \\
\hline
\end{tabular}

Means bearing different superscript letters within in the row significantly $(p<0.05)$ differ each other

${ }^{1}$ Calculated by a difference

shrimp fed test diets (1.11 to $1.18 \%$ ) than those fed control $\operatorname{diet}(0.87 \%)$. The increased ether extract level with replacing marine sources was corroborated with the findings of Kausik et al. (2004), who suggested that this would be due to upgraded hepatic lipogenesis. Notwithstanding, Menoyo et al. (2004) observed higher activity of lipogenic enzymes in gilthead seabream fed diet with vegetable oil substituting fish oil. In our study, palm oil was used to formulate the iso-lipidic diet, as marine sources substitution would also be a reason for obtaining higher content of ether extract in shrimp carcass.

Fatty acid composition of the experimental diets (Table 2) has reflected to a certain extent shrimp carcass (Table 5). Fatty acids like 16:0, 18:1n-9 and 18:2n-6 were significantly $(p<0.05)$ higher in whole shrimp fed with partially substituted marine ingredients compared to control. The results are in agreement with other studies reporting the fatty acid pattern in shrimp species reflecting that of dietary lipids (P. indicus: Colvin, 1976; M. japonicus: Guary et al., 1976; Kayama et al., 1980; P. monodon: Millamena, 1989, Deering et al., 1997; P. vannamei: Gonzalez-Felix et al., 2002). However, certain fatty acids appeared to be actively synthesised and/or retained, because they were present in small amounts in the test diets due to partial replacement of marine sources, but their level was relatively high in shrimp carcass such as the case of arachidonic acid, EPA and DHA.

In contrast, palmitic acid (16:0) and oleic acid (18:1 n-9) were abundant in the test diets, but their proportion was reduced in the shrimp carcass. This sparing and retention of fatty acids had already been demonstrated in F. chinensis (Xu et al., 1994), P. monodon (Deering et al., 1997) and P. vannamei (Gonzalez-Felix et al. (2002). The authors suggested that this phenomenon is probably due to the diversion of short and medium chain fatty acids towards energy production, whereas longer-chain unsaturated fatty acids would be selectively retained by the body similar to our observations in the present study. The fatty acids like EPA and DHA are readily available in marine sources, in particular fishmeal and fish oil and hence their level was high in shrimp fed the control diet (no replacement). Though their level was significantly reduced in shrimp reared with test diets (replaced diets), lyso-lecithin fed groups had higher EPA and DHA contents than soy-lecithin fed groups. The sum of SFAs and MUFAs increased in shrimp carcass due to the replacement of marine sources as in the respective experimental diet while the reverse trend was observed for PUFAs and HUFAs. The pattern of n-3, n- 6 fatty acids and their ratio was almost similar between the shrimp and the respective diet.

Among lipids (Fig. 1), phospholipids was dominated in shrimp carcass (56 to 63\%) compared to cholesterol (12 to $18 \%$ ) and triacylglycerides (9 to $13 \%$ ). Replacement of marine sources significantly $(\mathrm{p}<0.05)$ reduced phospholipid content in shrimp carcass and the reduction was lower with lyso-lecithin supplementation than soy-lecithin supplementation. Shrimp fed with control diet had a higher content of cholesterol than those fed test diets and same was in agreement with the finding of Cheng et al. (2004) in P. vannmei fed different protein and lipid sources. Similarly, body cholesterol lowering effect of diets containing vegetable oils was also earlier reported in shrimp (Kumaraguruvasagam et al., 2005) and fish (Richard et al., 2006). In addition, plant oils contain phytosterols which are known to decrease total cholesterol and LDL-cholesterol in man (Moghadasian and Frohlich, 1999; Matvienko et al., 2002; Vanstone et al., 2002) and in teleosts (Gilman et al., 2010), by decreasing intestinal cholesterol absorption efficiency (Normen et al., 2000; Vanstone et al., 2002). Though in the present study phytosterol levels were not measured, Phillips et al. (2002) reported that 
Table 5. Fatty acid composition ( $\%$ total fatty acid) of Penaeus monodon fed experimental diets ( $\mathrm{n}=3$; mean $\pm \mathrm{SD})$

\begin{tabular}{|c|c|c|c|}
\hline \multirow{2}{*}{ Particulars } & \multirow{2}{*}{ Control diet } & \multicolumn{2}{|c|}{ Test diets } \\
\hline & & Diet-SL & Diet-LL \\
\hline \multicolumn{4}{|c|}{ Saturated fatty acids (SFAs) } \\
\hline C14:0 & $0.95^{\mathrm{b}} \pm 0.12$ & $0.55^{\mathrm{a}} \pm 0.07$ & $0.61^{\mathrm{a}} \pm 0.05$ \\
\hline $\mathrm{C} 15: 0$ & $0.41^{\mathrm{a}} \pm 0.13$ & $0.39^{\mathrm{a}} \pm 0.11$ & $0.38^{\mathrm{a}} \pm 0.11$ \\
\hline $\mathrm{C} 16: 0$ & $17.72^{\mathrm{a}} \pm 0.89$ & $21.37^{\mathrm{b}} \pm 0.79$ & $22.89^{c} \pm 0.11$ \\
\hline $\mathrm{C} 17: 0$ & $0.85^{\mathrm{a}} \pm 0.13$ & $0.82^{\mathrm{a}} \pm 0.05$ & $0.82^{\mathrm{a}} \pm 0.16$ \\
\hline C18:0 & $7.75^{\mathrm{a}} \pm 0.70$ & $7.93^{\mathrm{a}} \pm 0.43$ & $7.91^{\mathrm{a}} \pm 0.79$ \\
\hline $\mathrm{C} 20: 0$ & $0.34^{\mathrm{a}} \pm 0.00$ & $0.34^{\mathrm{a}} \pm 0.03$ & $0.35^{\mathrm{a}} \pm 0.11$ \\
\hline $\mathrm{C} 22: 0$ & $0.39^{\mathrm{a}} \pm 0.07$ & $0.33^{\mathrm{a}} \pm 0.18$ & $0.36^{\mathrm{a}} \pm 0.15$ \\
\hline $\mathrm{C} 24: 0$ & $0.42^{\mathrm{a}} \pm 0.03$ & $0.41^{\mathrm{a}} \pm 0.12$ & $0.37^{\mathrm{a}} \pm 0.05$ \\
\hline \multicolumn{4}{|c|}{ Monounsaturated fatty acids (MUFAs) } \\
\hline $\mathrm{C} 16: 1$ & $1.21^{\mathrm{b}} \pm 0.02$ & $0.74^{\mathrm{a}} \pm 0.15$ & $0.84^{\mathrm{a}} \pm 0.04$ \\
\hline $\mathrm{C} 17: 1$ & $0.60^{\mathrm{a}} \pm 0.16$ & $0.54^{\mathrm{a}} \pm 0.14$ & $0.57^{\mathrm{a}} \pm 0.09$ \\
\hline C18:1n-9 & $11.88^{\mathrm{a}} \pm 0.83$ & $17.20^{\mathrm{b}} \pm 1.12$ & $17.77^{\mathrm{b}} \pm 1.53$ \\
\hline C18:1n-7 & $2.37^{\mathrm{a}} \pm 0.41$ & $2.38^{\mathrm{a}} \pm 0.24$ & $2.06^{\mathrm{a}} \pm 0.55$ \\
\hline C20:1 & $0.67^{\mathrm{a}} \pm 0.09$ & $0.62^{\mathrm{a}} \pm 0.09$ & $0.61^{\mathrm{a}} \pm 0.01$ \\
\hline $\mathrm{C} 24: 1$ & $0.32^{\mathrm{a}} \pm 0.06$ & $0.35^{\mathrm{a}} \pm 0.10$ & $0.34^{\mathrm{a}} \pm 0.08$ \\
\hline \multicolumn{4}{|c|}{ Polyunsaturated fatty acids (PUFAs) } \\
\hline C18:2n-6 & $15.75^{\mathrm{a}} \pm 0.33$ & $21.60^{\mathrm{b}} \pm 0.54$ & $21.70^{\mathrm{b}} \pm 0.66$ \\
\hline$C 20: 2 n-6$ & $1.15^{\mathrm{a}} \pm 0.42$ & $1.46^{\mathrm{a}} \pm 0.49$ & $1.21^{\mathrm{a}} \pm 0.37$ \\
\hline C $\gamma 18: 3 n-6$ & $0.40^{\mathrm{a}} \pm 0.06$ & $0.42^{\mathrm{a}} \pm 0.05$ & $0.39^{\mathrm{a}} \pm 0.10$ \\
\hline $\mathrm{Ca} 18: 3 n-3$ & $0.71^{\mathrm{a}} \pm 0.09$ & $0.70^{\mathrm{a}} \pm 0.14$ & $0.75^{\mathrm{a}} \pm 0.08$ \\
\hline C20:4n-6 & $3.46^{\mathrm{c}} \pm 0.07$ & $2.28^{\mathrm{a}} \pm 0.15$ & $2.92^{\mathrm{a}} \pm 0.14$ \\
\hline$C 20: 5 n-3$ & $11.36^{\mathrm{c}} \pm 0.36$ & $9.34^{\mathrm{a}} \pm 0.30$ & $10.39^{\mathrm{b}} \pm 0.26$ \\
\hline $\mathrm{C} 22: 6 n-3$ & $10.64^{\mathrm{c}} \pm 0.07$ & $8.36^{\mathrm{a}} \pm 0.24$ & $9.60^{b} \pm 0.53$ \\
\hline$\Sigma$ SFA & $28.87^{\mathrm{a}} \pm 1.61$ & $32.17^{\mathrm{b}} \pm 0.51$ & $33.68^{b} \pm 0.68$ \\
\hline$\Sigma$ MUFA & $17.07^{\mathrm{a}} \pm 1.08$ & $21.85^{\mathrm{b}} \pm 1.58$ & $22.17^{b} \pm 1.93$ \\
\hline$\Sigma$ PUFA and HUFA & $43.50^{\mathrm{a}} \pm 0.68$ & $44.19^{\mathrm{a}} \pm 0.50$ & $46.96^{\mathrm{b}} \pm 1.60$ \\
\hline$\Sigma \mathrm{n}-3$ & $22.72^{\mathrm{c}} \pm 0.23$ & $18.42^{\mathrm{a}} \pm 0.54$ & $20.73^{b} \pm 0.84$ \\
\hline$\Sigma \mathrm{n}-6$ & $20.78^{\mathrm{a}} \pm 0.48$ & $25.77^{b} \pm 0.82$ & $26.23^{b} \pm 0.78$ \\
\hline$n-3 / n-6$ & $1.09^{\mathrm{c}} \pm 0.01$ & $0.71^{\mathrm{a}} \pm 0.04$ & $0.79^{b} \pm 0.01$ \\
\hline
\end{tabular}

Means bearing different superscript letters within in the row significantly $(\mathrm{p}<0.05)$ differ

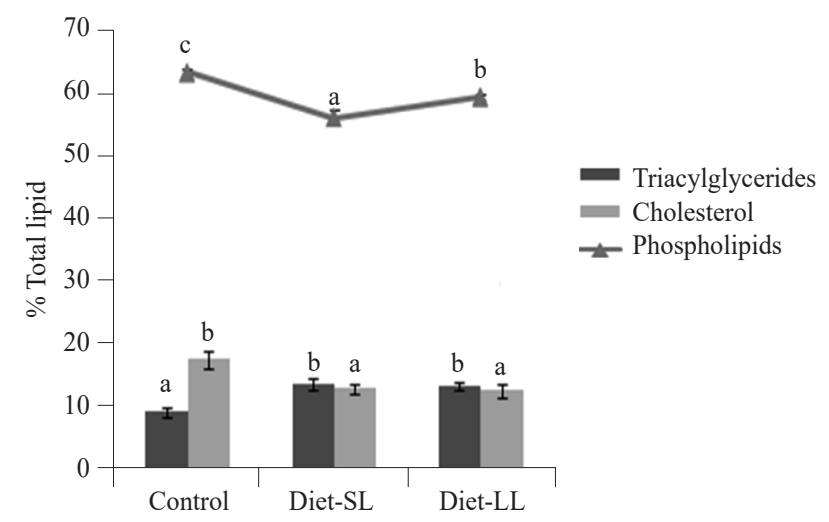

Fig. 1. Lipid class composition (\% total lipid) of Penaeus monodon fed experimental diets

palm oil had $0.5 \mathrm{~g} \mathrm{~kg}^{-1}$ of phytosterols, mainly sitosterol, campesterol and stigmasterol. Utilisation of palm oil in our study would also explain the hypocholesterolemic effect of the test diets in P. monodon. However, the present study is suggesting for further investigations to determine the mechanisms by which palm oil reduces shrimp body cholesterol. Higher content of triacylglycerides in shrimp fed with test diets compared to control is the reflection of the diet lipid composition.

The utilisation of marine ingredients has reached its peak in aquafeeds and further expansion of the aquafeed sector depends on the resilience of the sector to use alternative sustainable vegetable ingredients. The results of the present study are encouraging and confirmed that lyso-lecithin could be supplemented in shrimp practical diets for better performance in terms of growth and improved final product quality, in particular replacing marine sources using plant origins.

\section{Acknowledgements}

Authors express their sincere thanks to the present and former Directors, ICAR-CIBA, Chennai, India for extending 
all the infrastructure facilities to carry out the present work. ICAR, New Delhi, India is duly acknowledged for the financial assistance under Outreach Project.

\section{References}

Altech Survey 2015. Global feed survey. http://www.alltech. $\mathrm{com} / \mathrm{sites} /$ default/files/2015-global-feed-survey-slides.pdf (Accessed 26 December 2016)

AOAC 1995. Official methods of analysis, $16^{\text {th }}$ edn. Association of Official Analytical Chemists, Arlington, USA.

Bingkun, Z., Li, H., Dongqin, Z., Yuming, G. and Adriana, B. 2011. Effect of fat type and lysophosphatidylcholine addition to broiler diets on performance, apparent digestibility of fatty acids and apparent metabolisable energy content. Anim. Feed. Sci. Technol., 163: 177-184.

Catacutan, M. R. 1991. Growth and fatty acid composition of Penaeus monodon juveniles fed various lipids. Isr. J. Aquac. Bamidgeh, 43: 47-56.

Cheng, Z. J. and Hardy, R. W. 2004. Protein and lipid sources affect cholesterol concentrations of juvenile Pacific white shrimp, Litopenaeus vannamei (Boone). J. Anim. Sci., 82: 1136-1145.

Clarke, A. 1970. Lipid content and composition of the pink shrimp Pandalus montagui (Leach). J. Exp. Mar. Biol. Ecol., 38: 1-17.

Colvin, P. M. 1976. The effect of selected seed oils on the fatty acid composition of Penaeus indicus. Aquaculture, 8: 81-89.

Coutteau, P., Geurden, I., Camara, M. R., Bergot, P. and Sorgeloos, P. 1997. Review on the dietary effects of phospholipids in fish and crustacean larviculture. Aquaculture, 155: 149-164.

D'Abramo, L. R., Border, C. E., Dagger, G. R., Conklin, D. E. and Baum, N. A. 1980. Relationships among dietary lipids, tissue lipids and growth in juvenile lobsters. Proc. World Maric. Soc., 11: 335-345

D'Abramo, L. R. and Sheen, S. S. 1993. Polyunsaturated fatty acid nutrition in juvenile freshwater prawn Macrobrachium rosenbergii. Aquaculture, 115: 63-86.

Danicke, S., Kucinskas, A. and Jeroch, H. 2001. Feed value and possibilities of feed value improvement of soy products for broilers. Archiv Fur Geflugelkunde, 65: 157-167.

Dayal, J. S., Rajaram, V., Ambasankar, K. and Ahamad Ali, S. 2011. Sunflower oil cake as a replacement for fishmeal in feeds of tiger shrimp, Penaeus monodon reared in tanks and in net cages. Indian J. Mar. Sci., 40: 460-470.

Dayal, J. S., Ahamad Ali, S. A., Ambasankar, K. and Singh, P. 2003. Effect of dietary protein level on its in vitro and in vivo digestibility in the tiger shrimp Penaeus monodon (Crustacea: Penaeidae). Indian J. Mar. Sci., 32: 151-155.

Dayal, J. S., Ambasankar, K., Panigrahi, A., Ponniah, A. G., Ravichandran, P. and Ali, S. A. 2012. Low cost and low fishmeal feed for tiger shrimp Penaeus monodon. CIBA Technology Series-8, p. 1-10.
Deering, M. J., Fielder, D. R. and Hewitt, D. R. 1997. Growth and fatty acid composition of juvenile leader prawns, Penaeus monodon, fed different lipids. Aquaculture, 151: 131-141.

Fiske, C. H. and Subbarow, Y. 1925. The calorimetric determination of phosphorous. J. Biol. Chem., 66: 375-400.

Folch, J., Lees, M. and Sloane-Stanley, G. H. 1957. A simple method for the isolation and purification of total lipids from animal tissues. J. Biol. Chem., 226: 497-509.

Gilman, M. L., Davis, D. A., Rossi, W. Jr. and Perez-Velazquez, M. 2010. Evaluation of apparent digestibility coefficient of energy of various vegetable feed ingredients in Florida pompano, Trachinotus carolinus. Aquaculture, 310: 240-243.

Glencross, B. D. 1998. Effect of dietary phospholipids on digestion of neutral lipid by the prawn Penaeus monodon. J. World Aquacult. Soc., 29: 365-369.

Gonza'lez-Fe'lix, M. L., Lawrence, A. L., Gatlin, D. M. and Perez-Velazquez, M. 2002. Growth, survival and fatty acid composition of juvenile Litopenaeus vannamei fed different oils in the presence and absence of phospholipids. Aquaculture, 205: 325-343.

Gonza'lez-Fe'lix, M. L. and Perez-Velazquez, M. 2002. Current status of lipid nutrition of Pacific white shrimp Litopenaeus vannamei. In: Cruz-Suarez, L. E., Ricque-Marie, D., Tapia-Salazar, M., Gaxiola-Cortes, M. G. and Simoes, N. (Eds.), Advances in Nutrition, Acuicola VI. Memories of the VI International Symposium of Acuicola Nutrition, Cancun, Quintana Roo, Mexico.

Guary, J. C., Kayama, M., Murakami, Y. and Ceccaldi, H. J. 1976. The effect of a fat-free diet and compounded diets supplemented with various oils on moults, growth and fatty acid composition of prawn Penaeus japonicus. Aquaculture, 7: $245-254$.

IFFO 2009. International Fishmeal and Fish Oil Organisation. http://www.iffo.net (Accessed 17 November 2016).

Kanazawa, A., Teshima, S. and Tokiwa, S. 1977. Nutritional requirements of prawn: VII. Effect of dietary lipids on growth. Bull. Jpn. Soc. Sci. Fish., 43: 849-856.

Kaushik, S. J., Coves, D., Dutto, G. and Blanc, D. 2004. Almost total replacement of fishmeal by plant protein sources in the diet of a marine teleost, the European seabass, Dicentrarchus labrax. Aquaculture, 230: 391-404.

Kayama, M., Hirata, M., Kanazawa, A., Tokiwa, S. and Saito, M 1980. Essential fatty acids in the diet of prawn: III. Lipid metabolism and fatty acid composition. Bull. Jpn. Soc. Sci. Fish., 46: 483-488.

Khan, H. I., Dayal, J. S., Ambasankar, K., Madhubabu, E. P., Jannathulla, R. and Rajaram, V. 2018. Enhancing the dietary value of palm oil in the presence of lysolecithin in tiger shrimp, Penaeus monodon. Aquacult. Int., 26: 509-522.

Kontara, E. K. M., Djunaidah, I. S., Coutteau, P. and Sorgeloos, P. 1998. Comparison of native, lyso and hydrogenated soybean phosphatidylcholine as phospholipid source in the diet of postlarval Penaeus japonicus Bate. Arch. Anim. Nutr., 51: 1-19. 
Kumaraguruvasagam, K. P., Ramesh, S. and Balasubramanian, T. 2005. Dietary value of different vegetable oil in black tiger shrimp Penaeus monodon in the presence and absence of soy lecithin supplementation: Effect on growth, nutrient digestibility and body composition. Aquaculture, 250: 317-327.

Longmuir, L. T. 2002. Lecithin. In: Hubbard, A. T. (Ed.), Encyclopedia of surface and colloid science Marcel Dekker Inc., New York, USA, p. 2997-3006.

Matvienko, O. A., Lewis, D. S., Swanson, M., Arndt, B., Rainwater, D. L., Stewart, J. and Alekel, D. L. 2002. A single daily dose of soybean phytosterols in ground beef decreases serum total cholesterol and LDL cholesterol in young, mildly hypercholesterolemic men. Am. J. Clin. Nutr., 76: 57-64.

Melegy, T., Khaled, N. F., El-Bana, R. and Abdellatif, H. 2010. Dietary fortification of a natural biosurfactant, lyso-lecithin in broiler. Afric. J. Agr. Res., 5: 2886-2892.

Menoyo, D., Izquierdo, M. S., Robaina, L., Gines, R., Lopez-Bote, C. J. and Bautista, J. M. 2004. Adaptation of lipid metabolism, tissue composition and flesh quality in gilthead seabream (Sparus aurata) to the replacement of dietary fish oil by linseed and soyabean oils. Br. J. Nutr., 92: 41-52.

Merican, Z. O. and Shim, K. F. 1994. Lipid and fatty acid utilisation in adult Penaeus monodon fed diets supplemented with various oils. Aquaculture, 123: 335-347.

Metcalfe, L. D., Schmitz, A. A. and Pelka, J. R. 1966. Rapid preparation of fatty acid esters from lipids for gas chromatographic analysis. Annexe Chem., 38: 524-535.

Millamena, O. M. 1989. Effect of fatty acid composition of broodstock diet on tissue fatty acid patterns and egg fertilisation and hatching in pond-reared Penaeus monodon. Asian Fish. Sci., 2: 127-134.

Moghadasian, M. H. and Frohlich, J. J. 1999. Effects of dietary phytosterols on cholesterol metabolism and atherosclerosis: clinical and experimental evidence. Am. J. Med., 107: 588-594.

Normen, L., Dutta, P., Lia, A. and Andersson, H. 2000. Soy sterol esters and beta-sitostanol ester as inhibitors of cholesterol absorption in human small bowel. Am. J. Clin. Nutr., 71: $908-913$.

Panigrahi, A., Syama Dayal, J., Anand, S., Ghoshal, T. K., Ambasankar, K., Raja, R. A., Biswas, G., Saraswati, R., Ponniah, A. G., Ravichandran, P. and Ali, S. A. 2010. Low input-low cost shrimp farming system based on organic principles. CIBA Technology Series-3, p. 1-9.

Parekh, A. C. and Jung, D. H. 1970. Cholesterol determination with ferric acetate - uranyl acetate sulphuric acid, ferrous sulphate reagents. Anal. Chem., 42: 1423-1427.
Phillips, K. M., Ruggio, D. M., Toivo, J. I., Swank, M. A. and Simpkins, A. H. 2002. Free and esterified sterol composition of edible oils and fats. J. Food Compost. Anal., 15: 123-142.

Polin, D., Wing, T. L., Ki, P. and Pell, K. E. 1980. The effect of bile acids and lipase on absorption of tallow in young chicks. Poult. Sci., 59: 2738-2743.

Rajaram, V. 2010. Studies on the of plant protein sources in the diet of black tiger shrimp, Penaeus monodon with emphasis on protein metabolism. $\mathrm{Ph}$. D dissertation, University of Madras, India.

Rajaram, V., Syama Dayal, J., Ambasankar, K. and Ahamad Ali, S. 2012. Silk cotton cake as an alternate protein source in the diet of tiger shrimp, Penaeus monodon Fabricius 1798 and its effects on growth, nitrogen utilisation and metabolism. Indian J. Fish., 59: 101-110.

Reynier, M. O., Lafont, H., Crotte, C., Sauve, P. and Gerolami, A. 1985. Intestinal cholesterol uptake: comparison between mixed micelles containing lecithin or lyso-lecithin. Lipids., 20: $145-150$

Rice, E. C. 1970. Triglycerides in serum: Standard methods of clinical chemistry, Academic press, New York, p. 215-222.

Richard, N., Kaushik, S., Larroquet, L., Panserat, S. and Corraze, G. 2006. Replacing dietary fish oil by vegetable oils has little effect on lipogenesis, transport and tissue lipid uptake in rainbow trout (Oncorhynchus mykiss). Br. J. Nutr., 96: 299-309.

Schwarzer, K. and Adams, C. A. 1996. The influence of specific phospholipids as absorption enhancer in animal nutrition. Fett. Lipid., 98: 304-308.

Tacon, A. G. J. and Metian, M. 2008. Global overview on the use of fishmeal and fish oil in industrially compounded aqua feeds: Trends and future prospects. Aquaculture, 285: 146-158.

USDA 2017. Oilseeds: World markets and trade. Foreign Agricultural Service, Washington, D.C., USA.

Vanstone, C. A., Raeini-Sarjaz, M., Parsons, W. E. and Jones, P. J. 2002. Unesterified plant sterols and stanols lower LDL-cholesterol concentrations equivalently in hypercholesterolemic persons. Am. J. Clin. Nutr., 76: 1272-1278.

Xu, X., Wenjuan, J., Castell, J. D. and O’Dor, R. 1994. Essential fatty acid requirement of the Chinese prawn, Penaeus chinensis. Aquaculture, 127: 29-40.

Yi Hu., Tan, B., Mai, K., Ai, Q., Zhang, L. and Zheng, S. 2011. Effects of dietary menhaden oil, soybean oil and soybean lecithin oil at different ratios on growth, body composition and blood chemistry of juvenile Litopenaeus vannamei. Aquacult. Int., 19: 459-473.

Zubay, G. 1983. Biochemistry. Addison-Wesley. Reading, Mass, p. 138-206.

Date of Receipt $\quad$ : 08.09.2017

Date of Acceptance : 03.05.2018 